\title{
Pathogenic and opportunistic microorganisms in caves
}

\author{
Valme Jurado, Leonila Laiz, Veronica Rodriguez-Nava ${ }^{1}$, Patrick Boiron ${ }^{1}$, Bernardo \\ Hermosin, Sergio Sanchez-Moral ${ }^{2}$, Cesareo Saiz-Jimenez
}

\begin{abstract}
:
Jurado V., Laiz L., Rodriguez-Nava V., Boiron P., Hermosin H., Sanchez-Moral S. and Saiz-Jimenez C. 2010. Pathogenic and opportunistic microorganisms in caves. International Journal of Speleology, 39 (1), 15-24. Bologna (Italy). ISSN 0392-6672.

With today's leisure tourism, the frequency of visits to many caves makes it necessary to know about possible potentially pathogenic microorganisms in caves, determine their reservoirs, and inform the public about the consequences of such visits. Our data reveal that caves could be a potential danger to visitors because of the presence of opportunistic microorganisms, whose existence and possible development in humans is currently unknown.
\end{abstract}

Keywords: Caves, bacteria, fungi, virus, opportunistic pathogens

Received 26 Oktober 2009; Revised 28 November 2009; Accepted 9 December 2009.

\section{INTRODUCTION}

Europe is an exceptional continent for its abundance and variety of subterranean karstic forms comprising the natural geological heritage. Many of them are Protected Sites, and today many countries have programmes for the protection of caves and geodiversity. Some caves can be visited, and are, either ecologically or culturally, a tourist attraction. Today, many caves have been invaded by, and are important centres of, mass tourism. Nevertheless, while certain caves have around 500,000 visits annually (Grotta del Vento, Italy; Postojna caves, Slovenia; Nerja, Spain), others are difficult to get to, and are visited only by speleologists (Calaforra Chordi \& Berrocal Pérez, 2008).

With today's leisure tourism, the frequency of visits to many caves makes it necessary to know about possible potentially pathogenic microorganisms in caves, determine their reservoirs, and inform the public about the consequences of such visits for people who are immunosuppressed, undergoing chemotherapy,

1 Research Group on "Bacterial Opportunistic Pathogens and Environment", CNRS, Faculté de Pharmacie, Université de Lyon 1, UMR 5557 Ecologie Microbienne, 8, avenue Rockefeller, 69373, France

2 Museo Nacional de Ciencias Naturales, CSIC, Jose Gutierrez Abascal 2, 28006 Madrid, Spain

Instituto de Recursos Naturales y Agrobiologia, CSIC, Avenida Reina Mercedes 10, 41012 Sevilla, Spain or have lowered defences. Unfortunately, information on this topic is not well known, and visitors remain unaware. Determining the extent of the potential danger is of great interest - not only scientific, but also medical and social. Our data reveal that caves could be a potential danger to visitors, because of the presence of opportunistic microorganisms, whose existence and possible development in humans is currently unknown.

\section{CAVE MICROORGANISMS}

Microorganisms occupy all the niches of the biosphere, including subterranean ones. Underground habitats, represented essentially by caves, have no light, little or no organic nutrient load, a relatively constant temperature, and extensive areas of mineral surfaces.

The literature on microbial communities in subterranean environments is scant and chiefly restricted to caves found in Spain, Italy, France, Rumania, and the USA. Most of the existing literature refers to specific aspects, such as the taxonomic or geomicrobiological ones (Hernandez-Marine \& Canals, 1994; Northup \& Lavoie, 2001; Engel et al., 2003; Barton, \& Northup, 2007; Barton et al., 2007; Porter et al. 2009), to the effects on rock-art paintings (Schabereiter-Gurtner et al., 2002 a, b), or colonization by fungi (Dupont et al., 2007; Bastian et al., 2009b).

A review on the biodiversity and distribution of 
bacteria in subterranean environments reveals the scant knowledge of these topics. Proteobacteria represent the major portion of bacteria in caves when using molecular tools, but Actinobacteria constitute the majority of isolates (Groth et al., 1999; Barton et al. 2007), although it was formerly believed they were confined mainly to soils, their natural habitat (Porter, 1971; Goodfellow \& Williams, 1983). In the last decade, actinobacteria have been shown to be abundant in caves (Groth et al., 1999; Schabereiter-Gurtner et al., 2002 a,b; Jurado et al., 2005 a,c), suggesting that this is a habitat particularly favourable for this group of bacteria (Figure 1).

Table 1 shows the new species of actinobacteria isolated from subterranean environments reported since 2000, as gathered in the International Journal of Systematic and Evolutionary Microbiology. The identification of new species of the genera Agromyces, Amycolatopsis, and Kribbella (Figure 2) indicates that these environments constitute an ecological niche with a solid potential for the study of biodiversity. The conditions of high salinity in certain niches, and the stability of the microbial communities over the years, make these habitats of great interest and a target for in-depth study, to obtain an understanding not only of the processes forming natural microbial communities and of their role in the interaction with minerals, but

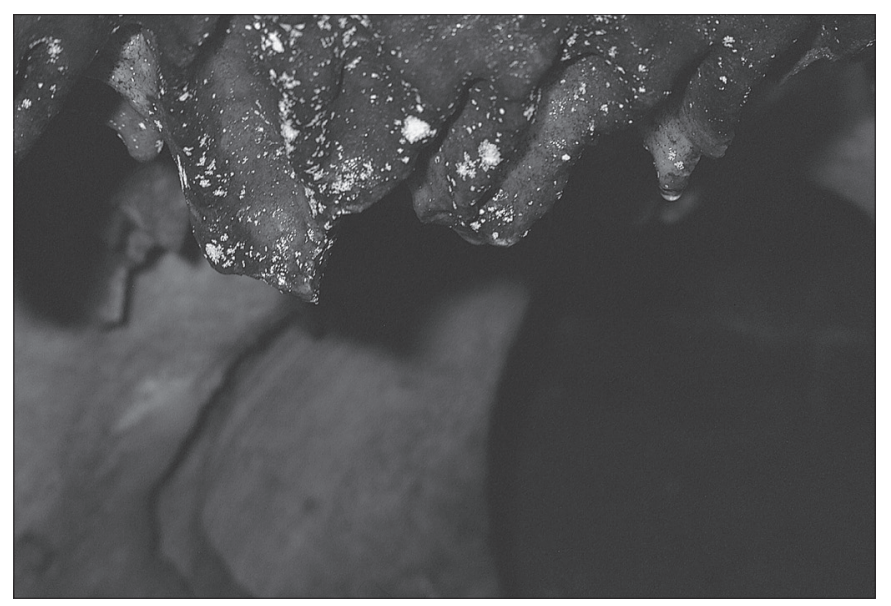

Fig. 1. Pseudonocardia sp. colonies in stalactites (Doña Trinidad Cave, Ardales, Spain).

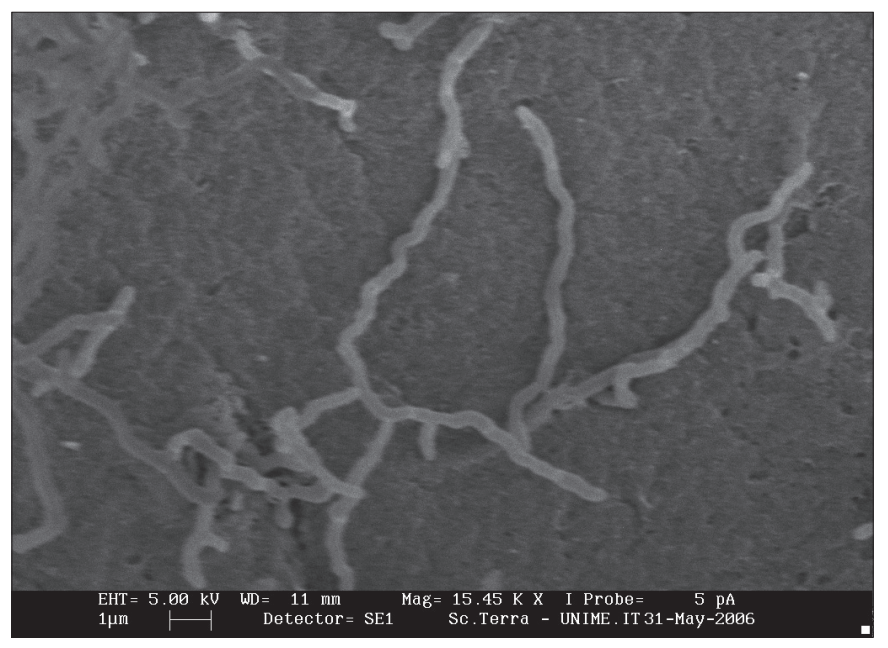

Fig. 2. Morphology of Kribbella catacumbae isolated from the catacomb of Saint Callistus, Rome, Italy. also of the biodiversity of such ecosystems.

At the same time, the ecological study of environments other than terrestrial and marine ones is important because of the potential of actinobacteria as producers of new bioactive substances derived from their secondary metabolism. In fact, the actinobacteria are an important source of naturally occurring (non-synthetic) antibiotics, besides substances with antiviral, antitumoural, immunological, and agrobiological (herbicidal) activity. All of these compounds are of high commercial value (Lemriss et al., 2003). A mathematical model estimates the number of undiscovered antimicrobials from the genus Streptomyces to be of the order of a 100,000 - a tiny fraction of which has been unearthed so far (Watve et al., 2001).

According to Williams et al. (1993), one possible way to tackle the isolation of new actinobacteria would be to focus on environments not studied or to investigate habitats in which one or various environmental factors (for example, temperature, $\mathrm{pH}$, aeration, osmotic stress, etc.) are extreme. Accordingly, the exploration of caves and their exploitation as reservoirs of bacteria is of great interest to the pharmaceutical industry. Groth \& Saiz-Jimenez (1999, 2002) pointed out the importance of caves as a new habitat in which actinobacteria producing bioactive substances could be found. Later, Herold et al. (2005) reported the production of cervimycin A-D by Streptomyces tendae, isolated from the Grotta dei Cervi, Porto Badisco, Italy. These novel polyketide glycosides have significant activity against multi-drug-resistant staphylococci and vancomycin-resistant enterococci.

Another important consideration is the presence of potentially pathogenic bacteria and fungi in isolations from caves, as can be observed in studies made by Groth et al. (1999), who isolated species of the genera Amycolatopsis, Aureobacterium, Brevibacterium, Nocardia, Nocardioides, Rhodococcus, Streptomyces, and the family Micrococcaceae. Some of the species of these genera have been catalogued as pathogenic - the diseases they cause come from contact with soils, waters, animal excrements, etc., which are their natural habitats. Human pathogenic fungi and yeasts are also common in caves (Sugita et al., 2005). We will focus our review on pathogenic microorganisms in caves.

\section{PATHOGENIC BACTERIA}

In recent years, the actinobacteria - and in particular the genera Nocardia, Mycobacterium, Gordonia, Rhodococcus and Streptomyces - have been the object of numerous studies at the international level (Nasher et al., 1989; Blanc et al., 2007 ; Mignard \& Flandrois, 2008; Rodríguez-Nava et al., 2008; El Karoui et al., 2009). All the above-mentioned genera, and many others, are widely found in isolations from caves.

The description of new species is in constant flux because of the new molecular methods developed in the last few years, considerably altering the taxonomic classification of these microorganisms. 
Table 1. New species of actinobacteria isolated from subterranean environments reported since 2000.

\begin{tabular}{|c|c|c|c|}
\hline & Actinobacteria Class & Origin & Reference \\
\hline 1 & Kribbella koreensis & Gold-mine Cave, Republic of Korea & Lee et al., 2000 a; Sohn et al., 2003 \\
\hline 2 & Catelliglobosispora koreensis & Gold-mine Cave, Republic of Korea & Lee et al., 2000 b; Ara et al., 2008 \\
\hline 3 & Saccharothrix violacea & Gold mine cave, Republic of Korea & Lee et a., 2000 c \\
\hline 4 & Saccharothrix albidocapillata & Gold mine cave, Republic of Korea & Lee et a., 2000 c \\
\hline 5 & Pseudonocardia kongjuensis & Gold mine cave, Republic of Korea & Lee et al., 2001 \\
\hline 6 & Knoellia sinensis & Reed Flute Cave, Guilin, China & Groth et al., 2002 \\
\hline 7 & Knoellia subterranea & Reed Flute Cave, Guilin, China & Groth et al., 2002 \\
\hline 8 & Pseudonocardia spinosispora & Gold-mine Cave, Republic of Korea & Lee et al., 2002 \\
\hline 9 & Arthrobacter psychrophenolicus & Alpine ice cave, Salzburg, Austria & Margesin et al., 2004 \\
\hline 10 & Agromyces salentinus & Grotta dei Cervi, Italy & Jurado et al., 2005 a \\
\hline 11 & Agromyces neolithicus & Grotta dei Cervi, Italy & Jurado et al., 2005 a \\
\hline 12 & Agromyces italicus & Roman catacombs, Italy & Jurado et al., 2005 b \\
\hline 13 & Agromyces humatus & Roman catacombs, Italy & Jurado et al., 2005 b \\
\hline 14 & Agromyces lapidis & Roman catacombs, Italy & Jurado et al., 2005 b \\
\hline 15 & Agromyces subbeticus & Cave of Bats, Córdoba, Spain & Jurado et al., $2005 \mathrm{c}$ \\
\hline 16 & Isoptericola hypogeus & Roman catacombs, Italy & Groth et al., 2005 \\
\hline 17 & Myceligenerans crystallogenes & Roman catacombs, Italy & Groth et al., 2006 \\
\hline 18 & Amycolatopsis jejuensis & Natural cave on Jeju Island, Republic of Korea & Lee, 2006 a \\
\hline 19 & Amycolatopsis halotolerans & Natural cave on Jeju Island, Republic of Korea & Lee, 2006 a \\
\hline 20 & Nocardia jejuensis & Natural cave on Jeju Island, Republic of Korea & Lee, 2006 b \\
\hline 21 & Actinocorallia cavernae & Natural cave on Jeju Island, Republic of Korea & Lee, 2006 c \\
\hline 22 & Amycolatopsis saalfeldensis & Medieval alum slate mine, Thuringia, Germany & Carlsohn et al., 2007 a \\
\hline 23 & Kribbella aluminosa & Medieval alud slate mine, Thuringia, Germany & Carlsohn et al., 2007 b \\
\hline 24 & Nocardia speluncae & Natural cave on Jeju Island, Republic of Korea & Seo et al., 2007 \\
\hline 25 & Amycolatopsis nigrescens & Roman catacombs, Italy & Groth et al., 2007 \\
\hline 26 & Kribbella catacumbae & Roman catacombs, Italy & Urzí et al., 2008 \\
\hline 27 & Kribbella sancticallisti & Roman catacombs, Italy & Urzí et al., 2008 \\
\hline 28 & Nocardia altamirensis & Altamira Cave, Cantabria, Spain & Jurado et al., 2008 \\
\hline 29 & Fodinicola feengrottensis & Medieval mine, Thuringia, Germany & Carlsohn et at., 2008 \\
\hline 30 & Jiangella alkaliphila & Natural cave on Jeju Island, Republic of Korea & Lee, 2008 \\
\hline 31 & Thermobifida halotolerans & Salt mine, Yunnan, China & Yang et al., 2008 \\
\hline 32 & Hoyosella altamirensis & Altamira Cave, Cantabria, Spain & Jurado et al., 2009 \\
\hline 33 & Fodinibacter luteus & Salt mine, Yunnan, China & Wang et al., 2009 \\
\hline 34 & Ferrimicrobium acidiphilum & Sulfur mine in North Wales, UK. & Johnson et al., 2009 \\
\hline
\end{tabular}

For example, the genus Mycobacterium includes more than 130 species (Mignard \& Flandrois, 2008), the genus Nocardia around 70 species (Rodríguez-Nava et al., 2008), the genus Rhodococcus 32 species, the genus Gordonia 21 species (Blanc et al., 2007), with other genera described in the literature having fewer species, such as Brevibacterium with 19 species, and Micrococcus with nine species. Some strains of these bacteria are responsible for different skin, lung, and/or brain infections in man. The most common primary location is the pulmonary system, with most clinical cases being reported in immunosuppressed patients, mainly associated to corticoids therapy, although immunocompetent hosts can also be affected. The secondary location is the central nervous system. In this case, the microorganisms also form abscesses inducing sensory, motor, and behavioural disturbances that differ depending on their location and the aetiological agent responsible, as well as nausea, headaches, and vomiting. Other, less common, locations are the eyes, the auditory apparatus (Iida et al., 2005), the lymphatic ganglia, the myocardium, the liver, etc. (Ghosheh et al., 2007 ; Rodríguez-Nava et al., 2007; Regnier et al., 2009; El Karoui et al., 2009).

In France, the "Observatoire Français des Nocardioses" (OFN) is a research centre whose main role is the identification at species level of bacteria of the genus Nocardia and the study of their patterns of sensitivity and resistance to antibiotics. The diagnosis of Nocardia is performed mostly in cultures and clinical samples from French hospitals. The result of such studies enables the OFN to conduct an epidemiological monitoring of nocardiosis in France (Rodriguez-Nava et al., 2008). The OFN also offers specific assistance to laboratories both in France and in the rest of the world.

At the same time, the research group "Bacteries Pathogènes Opportunistes et Environnement" of the "CNRS 5557 d'Ecologie Microbienne" carries out studies on the distribution and abundance of pathogenic species of actinobacteria, in particular of the genus 
Nocardia, in French soils, aimed at evaluating the risk of community infections associated with certain human activities (agriculture, speleology, mining, gardening, etc.), especially in immunosuppressed persons. In addition, there are other projects to characterise and define new actinobacteria species of clinical and environmental origin, in cooperation with various laboratories (Betrán et al., 2009).

The OFN annually records from 150 to 250 clinical cases due to Nocardia. The main pathogens identified are $N$. farcinica $(26 \%), N$. nova $(20 \%), N$. abscessus $(18 \%)$, and $N$. cyriacigeorgica (12\%) (Rodríguez-Nava et al., 2008). The isolation of Nocardia species in caves is relatively frequent (Groth et al., 1999; Lee, 2006 b; Seo et al., 2007; Jurado et al., 2008), although, at present, there is no information on the pathogenicity of these new species of Nocardia.

Species of the genus Gordonia, such as $G$. bronchialis, G. otitidis, G. aichiensis, and G. terrae are described in the literature as opportunistic pathogens responsible for bacteraemias and bronchopulmonary diseases (Iida et al. 2005; Blanc et al. 2007). Species of Gordonia have been isolated from Grotta dei Cervi, Italy, and some of them could represent new species, waiting to be described. This genus is of great interest in biotechnology because of its biodegrading and bioremediation capacities, as is the case of the species Gordonia nitida, able to desulphurate fuels (Lee et al., 2005).

In the genus Rhodococcus, the main pathogenic species is $R$. equi (Paasche, 2009). Nevertheless, $R$. erythropolis is also a pathogenic species that has been reported in clinical cases (Vernazza et al., 1991). The latter is frequently isolated from caves in northern Spain (Groth et al., 1999). The genera Brevibacterium and Micrococcus have been little studied, and few clinical cases are reported in the literature. Species of the genus Brevibacterium, such as B. casei and B. epidermis, are found in the human skin flora and are responsible for opportunistic infections (Reinert et al., 1995). Of the genus Micrococcus, the species M. luteus is known to be related with skin diseases, and to affect mainly immunocompromised patients (Salar et al., 1997). Streptomyces somaliensis is the most incidental aetiological agent of actinomycetoma in countries such as Sudan and India (Nasher et al. 1989). Actinomycetoma is also caused by Nocardiopsis dassonvillei (Ajello et al., 1987). This actinobacterium was found on the stalactites of Grotta dei Cervi, Italy (Figure 3), and it should be regarded as a potential nosocomial pathogen (Beau et al. 1999).

In Altamira Cave, Spain, a new genus and species of actinobacterium, Hoyosella altamirensis, has recently been isolated and described (Jurado et al., 2009). Phylogenetic data group Hoyosella with the Mycobacterium genus. The problem lies in knowing whether environmental bacteria are potentially pathogenic or not. It would be of interest to be able to confirm beyond doubt the existence of pathogenic species of these genera of actinobacteria in little-explored natural ecological niches, such as subterranean ones, to evaluate their potential, besides

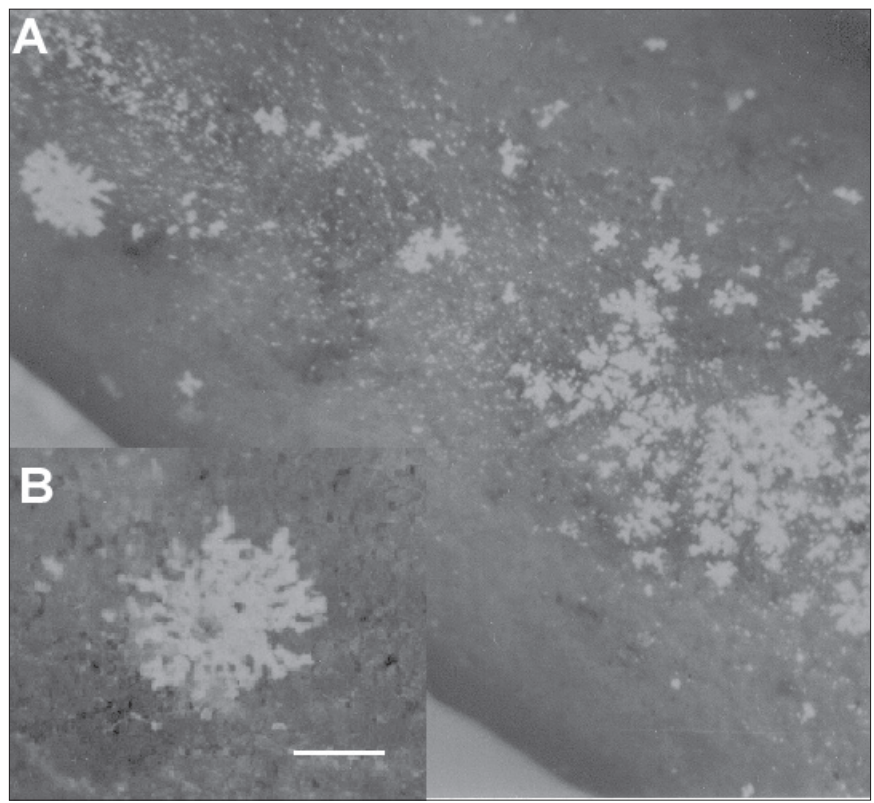

Fig. 3. Nocardiopsis dassonvillei on a stalactite (A). Detail (B). Bar is $1 \mathrm{~mm}$. (Grotta dei Cervi, Porto Badisco, Italy).

their diversity and role in such environments.

There is also evidence of the existence of a large reservoir of pathogenic bacteria belonging to the phylum Proteobacteria in visitable caves. For example, recently in Spanish caves have been possible to isolate species of alphaproteobacteria, such as those of the genus Inquilinus limosus, a novel emerging pathogen in cases of cystic fibrosis (Schmoldt et al. 2006) and the genus Afipia (associated to protozoa) and likely responsible for nosocomial diseases (La Scola et al., 2002). In addition, reservoirs of Legionella (gammaproteobacteria) have been detected in Lascaux Cave, France, by the use of molecular techniques (Bastian et al., 2009a). Lavoie \& Northup (2006) found a few bacteria in caves, which were considered indicators of human impacts, such as Staphylococcus aureus (Firmicutes).

With regard to the genus Aurantimonas (alphaproteobacteria), interesting clinical cases have been reported due to Aurantimonas altamirensis - a bacterium isolated and described in 2006 from Altamira Cave (Jurado et al., 2006). Two years later, the second isolation of this species in the world was performed in a Canadian hospital, obtaining it from three different patients suffering from cystic fibrosis, keratitis, or corneal ulcer (Luong et al., 2008). The latest isolation of this species took place in a hospital in Indianapolis, where it was described as an agent responsible for bacteraemia (Mendes et. al., 2009). We foresee that in the future, the number of clinical cases due to A. altamirensis will increase, as the clinicians now have the possibility to compare and identify patients' strains with the sequences deposited in the GenBank or the type strain deposited in culture collections.

Spirochaetes are frequent in caves. Bats and rodents are reservoirs of leptospirosis and they are numerous in tropical caves, which maximize leptospirosis exposure. High heat and humidity lead to minimal protective clothing, and frequent contact with rock 
results in multiple abrasions, a known portal of entry for the organism (Mortimer, 2005).

Relapsing fever borreliosis is another disease related to caves. A tick is the vector of Borrelia spp. and is widely distributed throughout India and Kashmir, the southern countries of the former USSR, Iran, Iraq, Syria, Jordan, Turkey, Israel, Cyprus, and Egypt. In Israel, 30-60\% of caves were found to be infested by Ornithodoros tholozani, the most important tick vector of Borrelia persica, causing tick-borne relapsing fever. O. tholozani mainly feeds on rodents and small mammals, which constitutes the natural reservoir. As far as the civilian population is concerned, $86 \%$ of the infestation foci were caves and $5 \%$ were ruins, and individual cases were recorded in areas of rocks and beside animal burrows. There have also been cases where persons who sat or lay on the ground at a distance of several metres from an infestation focus have been infected with Borrelia spp. (Assous \& Wilamowski, 2009).

\section{PATHOGENIC FUNGI}

With regard to fungi and yeasts, there are references to histoplasmosis caused by the fungus Histoplasma capsulatum, found in soils and caves inhabited by bats. This fungus produces pulmonary histoplasmosis, relatively frequent in cave explorers (Nieves-Rivera et al., 2009).

Skoulidis et al. (2004) reported that a patient regularly exposed to soil in bat caves was infected by the fungus Penicillium marneffei. Airborne infection was probably the main route of acquisition.

In the last few years, white-nose syndrome has caused a devastating epizootic among bats of the north-eastern US, and the disease continues to spread rapidly. The causal agent of the syndrome is a new fungus, Geomyces destructans. It appears that bats have lowered immune responses during hibernation torpor, which may predispose them to infection by G. destructans (Gargas et al., 2009). Another Geomyces, G. pannorum, is a ubiquitous saprophytic fungus frequently isolated from cave sediments, air samples and bat guano. This species is widely distributed in some European caves (Bastian et al. 2009 b; Nováková, 2009). It is an occasional aetiological agent of superficial infection of skin and nails in humans (Christen-Zaech et al., 2008).

The dermatophytes Microsporum gypseum and Trichophyton mentagrophytes have been isolated from soils and caves inhabited by bats (Kajihiro, 1965). An abundance of species of the genus Trichosporon (yeasts) has recently been found in Ardales Cave, Málaga, Spain (Stomeo, 2008). Bats are present in Ardales Cave and in Murciélagos Cave, in Córdoba, Spain. This genus is commonly isolated from guano, and bat guano is a rich source of yeasts and still-undiscovered species (Sugita et al., 2005).

To date, 21 species of Trichosporon have been described, some of them psychrophiles, others associated to animals, and five of them have a marked clinical nature (de Hoog et al., 2000). T. laibachii is the most common species, with a distribution in soils, sands, mud, and plant residues (Domsch et al., 2007). It is not associated with humans, and can be clearly distinguished from the pathogenic species T. asahii, T. asteroides, T. cutaneum, T. inkin, and T. mucoides by molecular methods. Sugita et al. (2005) found new species in bat guano in Japanese caves, and included them in four different serotypes. $T$. laibachii and T. multisporum are included in the group I-III serotype of Sugita et al. (2005). Each serotype is associated to the production of pneumonitis. None of the five pathogenic species have been found in preliminary studies carried out in Ardales Cave, but the number of samplings was small (only two), requiring subsequent studies and a more exhaustive sampling.

Vaughan-Martini et al. (2000), found that high counts of blastomycetes (yeasts and yeast-like fungi) in caves were in direct relation to the frequency of human or animal visits. Apparently, excessive human visits were also responsible for the fact that six of the ten yeast strains isolated have a direct relationship with human pathology.

\section{VIRUS IN CAVES}

Several outbreaks of Marburg hemorrhagic fever have been reported in Africa. Between 1998 and 1999 were identified 154 cases of Marburg hemorrhagic fever (case fatality rate, 83 percent) in a gold-mining village in D.R. of the Congo (Bausch et al., 2005). Fifty two percent of cases were in young male miners, working in the mine. Animals found in the mine included bats, rodents, and others, and the environment was heavily soiled with human and bat excrements. Cessation of the outbreak coincided with flooding of the mine. Bausch et al. (2005) concluded that the reservoir hosts of Marburg virus inhabit caves, mines, or similar habitats.

Towner et al. (2007) identified Marburg virus in common African bats, which were also to be likely reservoirs for Ebola virus. Osborne et al. (2003) identified Kaeng Khoi virus in dead bats in Cambodia.

In 2007, miners working in Kitaka Cave, Uganda, were diagnosed with Marburg hemorrhagic fever. The likely source of infection in the cave was Egyptian fruit bats (Rousettus aegyptiacus) based on detection of Marburg virus RNA. The bat colony was estimated to be over 100,000 animals using mark and re-capture methods, predicting the presence of over 5,000 virus-infected bats. The genetically diverse virus genome sequences from bats and miners closely matched. These data indicate common Egyptian fruit bats can represent a major natural reservoir and source of Marburg virus with potential for spillover into humans (Towner et al., 2009). Recently, a Dutch woman who was brushed by a fruit bat in a cave in the Maramagambo Forest, Uganda, died of Marburg hemorrhagic fever. The World Health Organization has warned people not to go into Ugandan caves with bats, after this Dutch tourist contracted the deadly Marburg virus (Timen et al. 2009).

\section{ENVIRONMENTAL VS PATHOGENIC MICROORGANISMS}

The pathogens up to day found and/or isolated from caves (Aurantimonas, Legionella, Staphylococcus, Inquilinus, Afipia, etc.) represent a danger for humans 
specially to risk groups. However, the virulence level of these microorganisms is not always constant within strains of the same species. This may rely on the characteristics of the ecological niche the strain was isolated from that may lead to acquire or to develop different pathogenicity factors.

Also, the fact that not many clinical reports of these microorganisms exist may give the false sensation that just a few strains of these species are pathogens. Even if this may be true, we must take in mind that this could be because i) the detection methods are relatively new because it refers to a newly described species, ii) it is not very present in the environment, iii) it is an opportunistic pathogen that requires special conditions of the immunity system of the host that fortunately are not so common.

It is important, apart from detecting the presence of pathogens in caves, to be able of quantifying this presence by using culture methods and by quantitative PCR. On the other side, it would also be interesting to obtain information about the infectious capacity of the pathogen strains isolated in caves by the means of animal experimentation, studying their virulence capacities with direct PCR methods using virulence genes as markers and by other hosts interaction tests (amoebae, mices, insects, etc.)

There exists a high risk, due to the presence of man in caves, of a bacteria passage from man to the cave that may lead to the development of new bacterial lines with many different pathogenic levels. This phenomenon can be evaluated by the measure of human indicator bacteria as proposed by Lavoie $\&$ Northup (2006). On the other side, the adaptive factors after a strain exchange (from man to cave and vice-versa) can be known by transcriptoma and comparative genomic studies.

\section{CONCLUDING COMMENTS}

Densely visited or animal-populated caves are reservoirs of pathogenic microorganisms. In recent years, a number of bacteria, fungi and viruses inhabiting caves have been reported to be pathogens for humans and animals. This is particularly dangerous in tropical areas. Although it is difficult to associate a specific infection to a single visit to a subterranean environment, several medical reports indicate that caves visits and mining activities in Africa result in diseases and fatal casualties.

Recommendations are often included in several papers. Jülg et al. (2008) reported that "Advice regarding histoplasmosis prevention should be given not only to bat researchers and to tourists planning to visit bat-infested caves but also to those who merely watch large groups of bats. In the case of caves with very large bat colonies, infection is a possibility even in the cave entrance, with no bats present. Histoplasmosis should be considered in the differential diagnosis of febrile illness in returning travelers with a history of epidemiologic or geographic exposure".

Assous \& Wilamowski (2009) stated that "public education concerning the risks involved in entering caves, combined with prevention measures in countries in which ticks lives primarily in caves and similar sites, is effective in reducing the number of cases. Persons entering caves must wear appropriate shoes and clothes covering all the body. It is recommended to spray shoes and the trouser bottoms with a repellant. Avoidance of long stays in caves reduces the opportunities for ticks to identify the host. Sleeping in caves or at nearby sites must be avoided. If it is necessary to stay in caves or at archaeological or similar sites for an extended period, it is necessary to monitor whether the place is infested with ticks, and to spray the site with suitable residual insecticides. It is recommended to spray the ground until it is wet and the walls of the cave up to a height of $1 \mathrm{~m}$. If prolonged work is necessary, the work should be stopped for several days for respraying".

The most-frequent diseases produced by cave microorganisms are located in the respiratory system and, therefore, it is recommended that visitors should, at the least, wear protective masks. Visits to any subterranean environment should possibly no longer be looked upon as a simple, riskless tourist activity, rather as one with potential risks for human health, particularly for the ill and elderly.

The study about diversity and abundance of pathogens in caves will allow us to set preventive actions for the exposed populations and for the risk populations overall. To decrease the number of cave-associated diseases it is necessary to increase the awareness and education of the public about the danger of entering caves and the need to take preventive control measures in caves and other subterranean environments.

\section{ACKNOWLEDGEMENTS}

Funding from the project RNM-5137, Consejería de Innovación, Junta de Andalucía, is acknowledged. This is also a TCP CSD2007-00058 paper. The collaboration of Dr. Clara Urzi, University of Messina, Italy, for providing Figure 2 is highly appreciated. This paper has benefited from the helpful comments of referees.

\section{REFERENCES}

Ajello L., Brown J., Macdonald E. \& Head E., 1987. Actinomycetoma caused by Nocardiopsis dassonvillei. Archives of Dermatology, 123: 426.

Ara I., Bakir M. A. \& Kudo T., 2008 - Transfer of Catellatospora koreensis Lee et al. 2000 as Catelliglobosispora koreensis gen. nov., comb. nov. and Catellatospora tsunoense Asano et al. 1989 as Hamadaea tsunoensis gen. nov., comb. nov., and emended description of the genus Catellatospora Asano and Kawamoto 1986 emend. Lee and Hah 2002. International Journal of Systematic and Evolutionary Microbiology, 58: 1950-1960.

Assous M.V. \& Wilamowski A., 2009 - Relapsing fever borreliosis in Eurasia-forgotten, but certainly not gone! Clinical Microbiology \& Infection, 15: 407-414.

Barton H.A. \& Northup D.E., 2007 - Geomicrobiology in cave environments: past, current and future perspectives. Journal of Cave and Karst Studies, 69: 163-178. 
Barton H.A., Taylor N.T., Kreate M.P., Springer A.C., Oehrle S.A. \& Bertog J.L., 2007 - The impact of host rock geochemistry on bacterial community structure in oligotrophic cave environments. International Journal of Speleology 36: 93-104.

Bastian F., Alabouvette C. \& Saiz-Jimenez C., 2009a Bacteria and free-living amoeba in the Lascaux Cave. Research in Microbiology, 160: 38-40.

Bastian F., Alabouvette C. \& Saiz-Jimenez C., 2009 b The impact of arthropods on fungal community structure in Lascaux Cave. Journal of Applied Microbiology, 106: 1456-1462.

Bausch D.G., Nichol S.T., Muyembe-Tamfum J.J. et al., 2006 - Marburg hemorrhagic fever associated with multiple genetic lineages of virus. The New England Journal of Medicine, 355: 909-919.

Beau F., Bollet C., Coton T., Garnotel E. \& Drancourt M., 1999 - Molecular identification of a Nocardiopsis dassonvillei blood isolate. Journal of Clinical Microbiology, 37: 3366-3368.

Betrán A., Rezusta A., Lezcano M.A., Villuendas M.C., Revillo M.J., Boiron P. \& Rodríguez-Nava V., 2009 First Spanish case of nocardiosis caused by Nocardia takedensis. Journal of Clinical Microbiology, 47: 19181919.

Blanc V., Dalle M., Markarian A., Debunne M. V., Duplay E., Rodriguez-Nava V. \& Boiron P., 2007 - Gordonia terrae: a difficult-to-diagnose emerging pathogen? Journal of Clinical Microbiology, 45: 1076-1077.

Calaforra Chordi J.M. \& Berrocal Pérez J.A., 2008 - El Karst de Andalucía. Consejería de Medio Ambiente, Sevilla, 247 p.

Carlsohn M. R., Groth I., Tan G. Y. A., Schütze B., Saluz H.-P., Munder T., Yang J., Wink J. \& Goodfellow M., 2007 a - Amycolatopsis saalfeldensis sp. nov., a novel actinomycete isolated from a medieval alum slate mine. International Journal of Systematic and Evolutionary Microbiology, 57: 1640-1646.

Carlsohn M. R., Groth I., Spröer C., Schütze B., Saluz H.-P., Munder T. \& Stackebrandt E., 2007 b - Kribbella aluminosa sp. nov., isolated rom a medieval alum slate mine. International Journal of Systematic and Evolutionary Microbiology, 57: 1943-1947.

Carlsohn M. R., Groth I., Saluz H.-P., Schumann P. \& Stackebrandt E., 2008 - Fodinicola feengrottensis gen. nov., sp. nov., an actinomycete isolated from a medieval mine. International Journal of Systematic and Evolutionary Microbiology, 58: 1529-1536.

Christen-Zaech S., Patel S. \& Mancini A. J., 2008 Recurrent cutaneous Geomyces pannorum infection in three brothers with ichthyosis. Journal of the American Academy of Dermatology, 58: S112-S113.

Domsch K.H., Gams W. \& Anderson T.H., 2007 Compendium of Soil Fungi. $2^{\text {nd }}$ edition, IHW-Verlag, Eching, $672 \mathrm{p}$.

Dupont J., Jacquet C., Dennetière B., Lacoste S., Bousta F., Orial G., Cruaud C., Couloux A. \& Roquebert M. F., 2007 - Invasion of the French Paleolithic painted cave of Lascaux by members of the Fusarium solani species complex. Mycologia, 99: 526-533.
El Karoui K., Guillet C., Sekkal N., Lanternier F., Méchai F., Hue K., Hiesse C., Mamzer Bruneel M.F., Catherinot E., Viard J.P., Mainardi J.L., Lecuit M., Ferroni A., Lortholary O., 2009 - Synergistic effect of carbapenemteicoplanin combination during severe Rhodococcus equi pneumonia in a kidney transplant recipient. Transplant Infectious Disease, 11: 359-362.

Engel A.S., Lee N., Porter M.L., Stern L.A., Bennett P.C., Wagner M., 2003 - Filamentous "Epsilonproteobacteria" dominate microbial mats from sulfidic cave springs. Applied and Environmental Microbiology, 69: 55035511.

Gargas A., Trest M.T., Christensen M., Volk T.J. \& Blehert D.S., 2009 - Geomyces destructans sp. nov. associated with bat white-nose syndrome. Mycotaxon, 108: 147154.

Ghosheh F.R., Ehlers J.P., Ayres B.D., Hammersmith K.M., Rapuano C.J. \& Cohen E.J., 2007 - Corneal ulcers associated with aerosolized crack cocaine use. Cornea, 26: 966-9.

Goodfellow M. \& Williams S. T., 1983 - Ecology of actinomycetes. Annual Review of Microbiology, 37: 189216.

Groth I. \& Saiz-Jimenez C., 1999 - Actinomycetes in hypogean environments. Geomicrobiology Journal, 16: 1-8.

Groth I. \& Saiz-Jimenez C., 2002 - Actinomycetes in caves. Coalition, 4: 12-14.

Groth I., Vetermann R., Schuetze B., Schumann P. \& Saiz-Jimenez C., 1999 - Actinomycetes in kartic caves of Northern Spain (Altamira and Tito Bustillo). Journal of Microbiological Methods, 36: 115-122.

Groth I., Schumann P., Schutze B., Augsten K. \& Stackebrandt E., 2002 - Knoellia sinensis gen. nov., sp. nov. and Knoellia subterranean sp. nov., two novel actinobacteria isolated from a cave. International Journal of Systematic and Evolutionary Microbiology, 52: 77-84.

Groth I., Schumann P., Schüetze B., Gonzalez J. M., Laiz L., Saiz-Jimenez C. \& Stackebrandt E., 2005 - Isoptericola hypogeus sp. nov., isolated from the Roman catacomb of Domitilla. International Journal of Systematic and Evolutionary Microbiology, 55: 1715-1719.

Groth I., Schumann P., Schüetze B., Gonzalez J. M., Laiz L., Suihko M.-L. \& Stackebrandt E., 2006 - Myceligenerans crystallogenes sp. nov., isolated from Roman catacombs. International Journal of Systematic and Evolutionary Microbiology, 56: 283-287.

Groth I., Tan G. Y. G., Gonzalez J. M., Laiz L., Carlsohn M. R., Schütze B., Wink J. \& Goodfellow M., 2007 Amycolatopsis nigrescens sp. nov., an actinomycete isolated from a Roman catacomb. International Journal of Systematic and Evolutionary Microbiology, 57: 513-519.

Hernandez-Marine M, \& Canals T., 1994 - Herpyzonema pulverulentum (Mastigocladaceae) a new cavernicolous atmophytic and lime-incrusted cyanophyte. Algological Studies, 75: 123-136.

Herold K., Gollmick F. A., Groth I., Roth M., Menzel K-D., Möllmann U., Gräfe U. \& Hertweck C., 2005 Cervimycin A-D: A polyketide glycoside complex from a cave bacterium can defeat vancomycin resistance. Chemistry, A European Journal, 11: 5523-5530. 
Hoog G. S. de, Guarro J., Gene J. \& Figueras M. J., 2000 - Atlas of Clinical Fungi. Centraalbureau voor Schimmelcultures, Baarn, 1126 p.

Iida S., Taniguchi H., Kageyama A., Yazawa K., Chibana H., Murata S., Nomura F., Kroppenstedt R.M. \& Mikami Y., 2005 - Gordonia otitidis sp. nov., isolated from a patient with external otitis. International Journal of Systematic and Evolutionary Microbiology, 55: 1871-1876.

Johnson B., Bacelar-Nicolau P., Okibe N., Thomas A. \& Hallberg K.B., 2009 - Ferrimicrobium acidiphilum gen. nov., sp. nov. and Ferrithrix thermotolerans gen. nov., sp. nov.: heterotrophic, iron-oxidizing, extremely acidophilic actinobacteria. International Journal of Systematic and Evolutionary Microbiology, 59: 1082-1089.

Jülg B., Elias J., Zahn A., Köppen S., Becker-Gaab C., Bogner J.R., 2008. Bat-associated histoplasmosis can be transmitted at entrances of bat caves and not only inside the caves. Journal of Travel Medicine, 15: 133-136.

Jurado V., Groth I., Gonzalez J. M., Laiz L. \& SaizJimenez C., 2005a - Agromyces salentinus sp. nov. and A. neoliticus sp. nov. International Journal of Systematic and Evolutionary Microbiology, 55: 153-157.

Jurado V., Groth I., Gonzalez J. M., Laiz L., Schuetze B. \& Saiz-Jimenez C., 2005b - Agromyces italicus sp. nov., Agromyces humatus sp. nov. and Agromyces lapidis $s p$. nov., isolated from Roman catacombs. International Journal of Systematic and Evolutionary Microbiology, 55: 871-875.

Jurado V., Groth I., Gonzalez J. M., Laiz L. \& Saiz-Jimenez C., 2005 c - Agromyces subbeticus sp. nov., isolated from a cave in southern Spain. International Journal of Systematic and Evolutionary Microbiology, 55: 18971901.

Jurado V., Gonzalez J. M., Laiz L. \& Saiz-Jimenez C., 2006 - Aurantimonas altamirensis sp. nov., a member of the order Rhizobiales isolated from Altamira Cave. International Journal of Systematic and Evolutionary Microbiology, 56: 2583- 2585.

Jurado V., Boiron P., Kroppenstedt R. M., Laurent F., Couble A., Laiz L., Klenk H.P., Gonzalez J. M., SaizJimenez C., Mouniée D., Bergeron E. \& RodríguezNava V., 2008 - Nocardia altamirensis sp. nov., isolated from Altamira cave, Cantabria, Spain. International Journal of Systematic and Evolutionary Microbiology, 58: $2210-2214$.

Jurado V., Kroppenstedt R.M., Saiz-Jimenez C., Klenk H.P., Mouniée D., Laiz L., Couble A., Pötter G., Boiron P. \& Rodríguez-Nava V., 2009 - Hoyosella altamirensis gen. nov., sp. nov., a new member of the order Actinomycetales isolated from a cave biofilm,International Journal of Systematic and Evolutionary Microbiology, 59: 3105-3110.

Kajihiro E.S., 1965 - Occurrence of dermatophytes in fresh bat guano. Applied Microbiology, 13: 720-725.

La Scola B., Mallet M-N., Patrick A. D. Grimont P.A.D. \& Raoult D, 2002 - Description of Afipia birgiae sp. nov. and Afipia massiliensis sp. nov. and recognition of Afipia felis genospecies A. International Journal of Systematic and Evolutionary Microbiology, 52: 1773-1782.
Lavoie K.H. \& Northup D.E., 2006 - Bacteria as indicators of human impact in caves. In : Proceedings of the 17th National Cave and Karst Management Symposium, October 31 to November 4, 2005, Albany, New York. The NCKMS Steering Committee, pp. 40-47.

Lee S. D., 2006a - Amycolatopsis jejuensis sp. nov., and Amycolatopsis halotolerans sp. nov., novel actinomycetes isolated from a natural cave. International Journal of Systematic and Evolutionary Microbiology, 56: 549-553.

Lee S. D., 2006b - Nocardia jejuensis sp. nov., a novel actinomycete isolated from a natural cave on Jeju Island, Republic of Korea. International Journal of Systematic and Evolutionary Microbiology, 56: 559-562.

Lee S. D., 2006c - Actinocorallia cavernae sp. nov., isolated from a natural cave on Jeju, Korea. International Journal of Systematic and Evolutionary Microbiology, 56: 1085-1088.

Lee S. D., 2008 - Jiangella alkaliphila sp. nov., an actinobacterium isolated from a cave. International Journal of Systematic and Evolutionary Microbiology, 58: 1176-1179.

Lee S. D., Kang S. O. \& Hah Y. C., 2000a - Hongia gen. nov., a new genus of the order Actinomycetales. International Journal of Systematic and Evolutionary Microbiology, 50: 191-199.

Lee S. D., Kang S. O. \& Hah Y. C., 2000b-Catellatospora koreensis sp. nov., a novel actinomycete isolated from a gold-mine cave. International Journal of Systematic and Evolutionary Microbiology, 50: $1103-1111$.

Lee S. D., Kim E. S., Roe J. H., Jim J., Kang S.O. \& Hah Y. C., 2000 c - Saccharothrix violacea sp. nov., isolated from a gold mine cave, and Saccharothrix albidocapillata comb. nov. International Journal of Systematic and Evolutionary Microbiology, 50: $1315-1323$.

Lee S. D., Kim E. S., Min K. L., Lee W. Y., Kang S. O. \& Hah Y. C., 2001. Pseudonocardia kongjuensis sp. nov., isolated from a gold mine cave. International Journal of Systematic and Evolutionary Microbiology, 51: 1505-1510.

Lee S. D., Kim E. S., Kang S. O. \& Hah Y. C., $2002-$ Pseudonocardia spinosispora sp. nov., isolated from Korean soil. International Journal of Systematic and Evolutionary Microbiology, 52: 1603-1608.

Lee M., Kim M. K., Kwon M. J., Park B. D., Kim M. H., Goodfellow M. \& Lee S. T., 2005 - Effect of the synthesized mycolic acid on the biodegradation of diesel oil by Gordonia nitida strain LE31. Journal of Bioscience and Bioengineering, 100: 429-436.

Lemriss S., Laurent F., Couble A., Casoli E., Lancelin J.M., Saintpierre-Bonaccio D., Rifai S., Fassouane A. \& Boiron P., 2003 - Screening of nonpolyenic antifungal metabolites produced by clinical isolates of actinomycetes. Canadian Journal of Microbiology, 49: 669-674.

Luong M-L., Békal S., Vinh D.C., Lauzon D., Leung V., Al-Rawahi G.N., N. B., Burdz T. \& Bernard K., 2008. First report of isolation and characterization of Aurantimonas altamirensis from clinical samples. Journal of Clinical Microbiology, 46: 2435-2437. 
Margesin R., Schumann P., Spröer C. \& Gounot A.M., 2004 - Arthrobacter psychrophenolicus sp. nov., isolated from an alpine ice cave. International Journal of Systematic and Evolutionary Microbiology, 54: 2067-2072.

Mendes R.E., Denys G.A., Fritsche T.R. \& Jones N.R., 2009 - Case report of Aurantimonas altamirensis bloodstreaminfection. Journal of Clinical Microbiolology, 47: $514-515$.

Mignard S. \& Flandrois J. P., 2008 - A seven-gene, multilocus, genus-wide approach to the phylogeny of mycobacteria using supertrees. International Journal of Systematic and Evolutionary Microbiology, 58: 1432-1441.

Mortimer R.B., 2005 - Leptospirosis in a caver returned from Sarawak, Malaysia. Wilderness and Environmental Medicine. 16: 129-131.

Nasher M. A., Hay R. J., Mahgoub E. S. \& Gumaa S. A., 1989 - In vitro studies of antibiotic sensitivities of Streptomyces somaliensis--a cause of human actinomycetoma. Transactions of the Royal Society of Tropical Medicine and Hygiene, 83: 265-268.

Nieves-Rivera A. M., Santos-Flores C. J., Dugan F. M. \& Miller T. E., 2009 - Guanophilic fungi in three caves of southwestern Puerto Rico. International Journal of Speleology, 38: 61-70.

Northup D.E. \& Lavoie K.H., 2001 - Geomicrobiology of caves: A review. Geomicrobiology Journal, 18: 199-222.

Nováková A., 2009 - Microscopic fungi isolated from the Domica Cave system (Slovak Karst National Park, Slovakia). A review. International Journal of Speleology, 38: $71-82$.

Osborne J.C., Rupprecht C.E., Olson J.G., Ksiazek T.G., Rollin P.E., Niezgoda M., Goldsmith C.S., An U.S. \& Nichol S.T., 2003 - Isolation of Kaeng Khoi virus from dead Chaerephon plicata bats in Cambodia. Journal of General Virology, 84: 2685-2689.

Paasche S.R., 2009 - Rhodococcus equi infection in a surgical wound. Clinical Laboratory Science, 22:141-145.

Porter J. N., 1971 - Prevalence and distribution of antibiotic-producing actinomycetes. Advances in Applied Microbiology, 14: 73-92.

Porter M. L., Engel A. S., Kane T. C. \& Kinkle B. K., 2009 - Productivity-diversity relationships from chemolithoautotrophically based sulfidic karst systems. International Journal of Speleology, 38: 27-40.

Regnier S., Ouagari Z., Perez Z.L., Veziris N., Bricaire F. \& Caumes E., 2009 - Cutaneous miliary resistant tuberculosis in a patient infected with human immunodeficiency virus: case report and literature review. Clinical and Experimental Dermatology, 34: e690-e692.

Reinert R.R., Schnitzler N., Haase G., Lütticken R., Fabry U., Schaal K.P., \& Funke G., 1995 - Recurrent bacteremia due to Brevibacterium casei in an immunocompromised patient. European Journal of Clinical Microbiology \& Infectious Diseases, 14: 1082-1085.

Rodríguez-Nava V., Laurent F., Couble A. \& Boiron P., 2007 - Identification phénotypique et moléculaire des bactéries appartenant au genre Nocardia. Revue Francophone des Laboratoires, 391: 49-56.
Rodríguez-Nava V., Zoropoguy A., Laurent F., Blaha D., Couble A., Mouniée D., \& Boiron P., 2008 - La nocardiose, une maladie en expansion. Antibiotiques, 10: 115-127.

Salar A., Carratalà J., Fernández-Sevilla A., Marín D., \& Grañena A., 1997 - Pneumonia caused by Micrococcus species in a neutropenic patient with acute leukemia. European Journal of Clinical Microbiology \& Infectious Diseases, 16: 546-548.

Schabereiter-Gurtner C., Saiz-Jimenez C., Piñar G., Lubitz W. \& Rölleke C., 2002a - Altamira cave Paleolithic paintings harbor partly unknown bacterial communities. FEMS Microbiology Letter, 211: 7-11.

Schabereiter-Gurtner C., Saiz-Jimenez C., Piñar G., Lubitz, W. \& Rölleke C., 2002b - Phylogenetic 16S rRNA analysis reveals the presence of complex and partly unknown bacterial communities in Tito Bustillo cave, Spain, and on its Palaeolithic paintings. Environmental Microbiology, 4: 392-400.

Schmoldt S., Latzin P., Heesemann J., Griese M., Imhof A. \& Hogardt M., 2006 - Clonal analysis of Inquilinus limosus isolates from six cystic fibrosis patients and specific serum antibody response. Journal of Medical Microbiology, 55: 1425-1433.

Seo J. P., Yun Y.-W. \& Lee S. D., 2007 - Nocardia speluncae sp. nov., isolated from a cave. International Journal of Systematic and Evolutionary Microbiology, 57: 2932-2935.

Skoulidis F., Morgan M. S. \& MacLeod K. M., 2004 Penicillium marneffei: a pathogen on our doorstep? Journal of the Royal Society of Medicine, 97: 394-395.

Sohn K., Hong S. G., Bae S. K. \& Chun J., 2003 - Transfer of Hongia koreensis Lee et al. 2000 to the genus Kribbella Park et al. 1999 as Kribbella koreensis comb. nov. International Journal of Systematic and Evolutionary Microbiology, 53: 1005-1007.

Sugita T., Kikuchi K., Makimura K., Urata K., Someya T., Kamei K., Niimi M. \& Uehara Y., 2005 - Trichosporon species isolated from guano samples obtained from bat-inhabited caves in Japan. Applied Environmental Microbiology, 71: 7626-7629.

Stomeo F., 2008. Análisis de comunidades microbianas presentes en la cueva de Doña Trinidad (Ardales, Málaga) utilizando cultivos y métodos moleculares basados en $A D N$ y ARN. Ph D Thesis. University of Seville, Spain.

Timen A., Koopmans M.P.G., Vossen A.C.T.M., van Doornum G.J.J., Günther S., van der Berkmortel F., Verduin K.M., Dittrich S., Emmerich P., Osterhaus A.D.M.E., van Dissel J.T. \& Coutinho R.A., 2009. Response to imported case of Marburg hemorrhagic fever, the Netherlands. Emerging Infectious Diseases, 15: 1171-1175.

Towner, J.S., Amman, B.R., Sealy, T.K. et al., 2009 Isolation of genetically diverse Marburg viruses from Egyptian fruit bats. PloS Pathogens, 5: e1000536. doi:10.1371/journal.ppat.1000536.

Urzì C., De Leo F. \& Schumann P., 2008 - Kribbella catacumbae sp. nov., and Kribbella sancticallisti $s p$. nov., isolated from whitish-grey patinas in the catacombs of St Callistus in Rome, Italy. International Journal of Systematic and Evolutionary Microbiology, 58: 2090-2097. 
Vaughan-Martini A., Angelini P. \& Zacchi L., 2000 - The influence of human and animal visitation on the yeast ecology of three Italian caverns. Annals of Microbiology, 50: $133-140$.

Vernazza P.L., Bodmer T. \& Galeazzi R.L., 1991Rhodococcus erythropolis infection in HIV-associated immunodeficiency. Schweizerische Medizinische Wochenschrift, 121: 1095-1098.

Wang Z.-G., Wang Y.-Z., Liu J.-H.- Chen Y.-G., Zhang X.-X., Wen M.-L., Xu L.-H., Peng Q. \& Cui X.-L., 2009 - Fodinibacter luteus gen. nov., sp. nov., an actinobacterium isolated from a salt mine. International Journal of Systematic and Evolutionary Microbiology, 59: 2185-2190.
Watve M.G., Tickoo R., Jog M.M. \&, Bhole B.D., 2001 - How many antibiotics are produced by the genus Streptomyces? Archives of Microbiology, 176: 386309.

Williams S. T., Locci R., Beswick A. et al., 1993 Detection and identification of novel actinomycetes. Research in Microbiology, 144:653-656.

Yang L.-L., Tang S.-K., Zhang Y.-Q., Zhi X.-Y., Wang D., Xu L.-H. \& Li W.-J., 2008 - Thermobifida halotolerans sp. nov., isolated from a salt mine sample, and emended description of the genus Thermobifida. International Journal of Systematic and Evolutionary Microbiology, 58: 1821-1825. 